\title{
The Educational Values in the Kanca Seni Sedulur Sinorowadhi Puppet Reog Performances in Bantul
}

\author{
Paulus Metta Dwi Manggala Putra ${ }^{1 *}$ Kusnadi $^{2 * *}$
}

\author{
Graduate School, Yogyakarta State University, Yogyakarta, Indonesia \\ *Corresponding author, Email: kusnadi@uny.ac.id \\ **Corresponding author, Email: pmdmanggalaputra@gmail.com
}

\begin{abstract}
The research aims to find out the implicit and explicit educational values in the Kanca Seni Sedulur Sinorowadhi (KSSS) puppet reog performance in Bantul. This study used a qualitative method and an ethnography approach. There were primary and secondary data sources in this study. The analysis technique used data reduction, data display, and conclusions drawing. The results show that the performance of the KSSS puppet reog group was an art form that provides touches of creation both in the dance movements and in the musical accompaniment. Besides, the puppet reog performance provides religious, moral, social, and cultural educational values.
\end{abstract}

Keywords: educational values, puppet reog performance

\section{INTRODUCTION}

There have been various arts in Indonesia whose forms also vary, like dances, music, and fine arts that are located throughout the Indonesian archipelago. Each of these arts also develops in their home regions. Yogyakarta for example, has a variety of arts. This also encourages Yogyakarta to be one of the tourist destinations in Indonesia. Bantul is one of the districts in Yogyakarta, exactly located in the southern part of Yogyakarta. The arts in Bantul have been diverse, one of which is the Puppet Reog dance. People may hear the word "Reog" in a kind of Reog Ponorogo dance in East Java. However, Wayang Reog is one of the special arts in Bantul although there are still other traditional dances, such as Jathilan, Gedrug, and Angguk. Puppet Reog is a popular dance performance that refers to puppet-shop figures from both the Ramayana and Jagad Baratayudha. In general, the dance highlights the war-like dance in the performance. The dance does not accentuate the storyline but only displays war fragments or what in Javanese is said to be Beksan. In general, the war dances presented are popular war dances from the puppet figures of Ramayana and Baratayudha.

Puppet Reog groups are usually formed categorically based on their hamlets, but not all have such the art group. This dance show is an ancestral art passed on to the young generations in villages. If some hamlets do not have any Puppet Reog art group, the elders of the hamlet might not bequeath or learn the art. Puppet Reog performances are usually performed by young men and women who are trained by special trainers or local elders. This makes the art vary, but the theme of the dance performance shown is generally the same. The dance show is usually held on certain days for example on Indonesian Independence Day, the anniversary of the Reog Group, and if there is a request. For hamlets that have the art group, at least in a year, the
Reog group can perform twice. The dance itself is generally performed by 26 to 40 players each of whom has their respective roles featuring Ramayana and Baratayudha figures. Like most popular dances in this art is a war between evil and good characters. One of the roles that characterize the Puppet Reog performance is the role of the Buto army or the mythological giant creature who symbolizes the evil nature, and the role of the ape army symbolizing the nature of goodness. As for the place needed to display the art, space can be quite flexible because the dance can be performed anywhere when the place can accommodate all of the performers and audiences. Usually, the dance is displayed in the yard or field of local villagers.

Recently the art develops in the performance both in terms of movement and accompaniment music. However, there still exist some groups that still survive with the old kind commonly called the classical model. While those holding some development in movements and accompaniment music are often known as Creative Reog. In this study, the researchers aim to examine the Reog group Kanca Seni Sedulur Sinorowadhi or abbreviated KSSS. KSSS is one of the art troupes whose creations reveal dynamic dance movements and accompaniment music while still using and maintaining the grips of classical dance movements.

Talking about populist art means conversing culture. Culture can be defined as a set of social processes where social processes are spread and exchanged, which then produces meaning. The social process that is carried out continuously in the region that forms certain patterns is called culture. Likewise, it is also said that culture is a social aspect that occurs due to exchange, the continuous expansion of social processes and is usually associated with various social processes that affect the economy, law, and education. Cultural studies can be a tool to find out the signs and messages from the culture itself that can be learned in various ways and approaches [1]. In researching a particular 
culture, the most important thing and must be known is the culture that is examined itself, without knowing the culture to examine, it will be difficult to receive messages and signs that exist in it. In this paper, the culture to be examined is Javanese culture so that the cultural context used is the perspective of Javanese culture.

Whereas value is an abstract reality. Values differ from norms that are absolute in nature, they are more relative as they act as driving forces in life that give meaning and determine whether or not an action is valid. Values are also a foundation for changes in individuals and groups. Values, if judged from Scheler's theory, include a reality that exists, rather than assumed to exist. Although hidden behind various other realities, they do not depend on other realities. The nature of the values is absolutely unchanging. Values are not affected by changes occurring in objects pinned to that value. Scheler also believes that humans relate to values by means of the openness and sensitivity of their hearts, and they cannot understand just by thinking about the values but by experiencing and realizing them [2]. The Greeks have given their understanding of education as an effort to make humans into human beings, meaning to make humans into the whole people who have the ability to control themselves, have the knowledge and have a love for the motherland [3]. Education is everything related to learning activities that take place continuously or throughout the ages throughout life [4].

Puppet Reog shows performed by the KSSS group might become an interesting phenomenon to study since there were only a few researchers who upraised the theme of Puppet Reog. Besides, the performances of the KSSS group are creative kinds. Concerning this, that the problems of the study were formulated as follows. (1) What are the forms of the Puppet Reog performance of the KSSS group? 2) What are the educational values embedded in the Puppet Reog performances by KSSS? Therefore, this research aims to describe the form of KSSS Puppet Reog performances and to describe the educational values contained within the performing art.

\section{RESEARCH METHOD}

To achieve the research objectives, the ethnographic method was employed. It aims to reveal the culture of a certain ethnic, civilization, or society. Ethnography is a study that refers to both implied and explicit culture [5]. It tends to be more narrative in telling what is expressed by informants or research subjects and narrates the findings systematically [6]. The data sources are divided into two, namely the primary data source which involves interviews and observations conducted at the research setting, and the secondary data source covers documentation both in the form of videos and photos that can be found by the authors in the research location.

The research subjects involved in this research were trained KSSS Reog personnel. While data were analyzed by data collection, reduction, presentation, and drawing conclusions. The data validity test was performed by using a triangulation technique to review the interview data, draw conclusions, and confirm them to the informants whether the data collected were in accordance with what existed in the research location.

\section{RESUltS AND DisCUSSION}

\section{A. Forms of KSSS Puppet Reog Performances}

The KSSS Puppet Reog originates from Warungpring Bantul, Yogyakarta Special Province, Indonesia. The group members had been known to come from various regions in Bantul Regency. During the KSSS Puppet Reog performance, the following roles were played:

Table 1. The Puppet Roles

\begin{tabular}{|l|l|}
\hline \multicolumn{2}{|c|}{ Figures in the Puppet Reog } \\
\hline \multicolumn{1}{|c|}{ First Row } & \multicolumn{1}{c|}{ Second Row } \\
\hline Pembatak & Pembatak \\
\hline Dewi tara & Banowati \\
\hline Subadra & Dewi sinta \\
\hline Arjuna & Cakil \\
\hline Setyaki & Burisrawa \\
\hline Gatot kaca & Kartamarma \\
\hline Antareja & Dursasana \\
\hline Antasena & Lembusura \\
\hline Subali & Mahesasura \\
\hline Sugriwa & Buto \\
\hline Kera Rucah & Buto \\
\hline Kera Rucahn & Buto \\
\hline Kera Rucah & Buto \\
\hline Kera Rucah & Buto \\
\hline Kera Rucah & Buto \\
\hline Kera Rucah & Buto \\
\hline Kera Rucah & Rahwana \\
\hline Hanoman &
\end{tabular}

The above table provides a sequence of roles played by the KSSS group personnel when the research was conducted. The sequence of roles above might not be a standard, but the sequence refers to the play that will be performed at stage. Performances with the arrangement of the above roles describe the story of the death of Lembusura and Mahesasura. If the theme of the story is taken from the story of Hanoman Obong, for example, the arrangement of the roles displayed will be different from that of the table. A decision on the theme of the story can be the choice of the reog group, but if KSSS is asked to perform in a place with a request for a certain story, they can grant it. Besides, the make-up at the Puppet Reog show refers to that of the Wayang Wong, so the roles played are in accordance with the Yogyakarta-style puppet make-up. In the show, the role of Arjuna was played by a woman, from the information obtained, because Arjuna is described as a gentle and wellnatured figure, and if played by a man, the subtle movements made would be less flexible.

The dance was performed by the KSSS Puppet Reog group with a two-row floor pattern namely the first and second rows that form two parallel lines. The dancers then formed a large circle composed of two rows. In the next movement, the two circles facing each other to be continued with the 
dance of each role in pairs. When in line, they might not have a partner, and then when the war was danced three roles become one pair. From the movements shown, there were subtle movements usually displayed by the goddesses or women. Then there were figures who were gallant in characters, and in general, they were knights. Besides, the violent character depicted the roles of the giants and monkey army, but the role of the apes is more like the natural movements of apes.

In the Puppet Reog performance of KSSS, it was seen that each role had the character of the movement that was brought by each of them. The scene of the war usually begins with the war of the Pembatak then proceeds to the story of Baratayudha and Ramayana. The war of these roles was always won by both parties such as Burisrawa who wanted to take Sembadra, the wife of Arjuna, defeated by Setyaki and Gatotkaca. Then there was a war between Subali-Sugriwa who were twin monkeys who succeeded in defeating Lembusura and Mahesasura. Even though Lembusura and Mahesasura are told to have the gift of a god for not being able to die, they have acted greedily and arbitrarily to anyone. Like popular dance in general, these evils will always be inferior to goodness.

The accompanying music from the Puppet Reog dance of the KSSS group is relatively more dynamic. Where in general Puppet Reog only uses three bendhe, three dhodhog and kecrek as musical instruments. In the Puppet Reog show, the KSSS group used six bendhe, three dhodhogs, drums, snare drums, hi-hat, cymbals, and some additional bonang. From the kinds of musical instruments used to accompany the dance, it is clear that the musical accompaniment performed by KSSS group is more energetic where there are additional drums in general to provide certain beats. The accompaniment is almost the same as that of the classic Puppet Reog, but with more musical instruments such as drums to open the accompaniment of Puppet Reog performances.

The use of bonang is to fill in monotonous bende patterns. With this boning, accompaniment music becomes full and dynamic. Besides, the use of snare and cymbals makes a wonderful touch because it adds accents to the movement of war such as hitting or kicking. In addition to the use of these instruments at the KSSS musical accompaniment, there were also sounds of Javanese Macapat and melody. There are also songs that remind people of how to act well according to religious teachings. No wonder every art is inserted with religious elements because as heard, in the past these arts were used to spread religion, especially Islam in Yogyakarta.

\section{B. Educational Values in the KSSS Puppet Reog Performances}

Every performance will definitely give both implied and explicit meaning. This also means that a work of art will be widely accepted if it contains both meanings. Based on the observations, the Puppet Reog show contains the following educational values.

1) Religious educational values can be found in the messages conveyed in the songs, like tips for diligently praying, practicing worship, practicing religious teachings, and avoiding the prohibitions of the religion. The messages that were immediately conveyed became a religious education value, especially for the whole community who perform the show or watch it.

2) The moral educational values in this show are manifested in the stories that are displayed in this Puppet Reog show, such as in the fragment of the story of the battle of Burisrawa and Setyaki which fought due to Burisrawa's desire to take forcibly Subhadra. Although Burisrawa is strong, he still lost to the figure of Setyaki who preserves the truth. Likewise, the story of Subali-Sugriwa who fought against the King of the Giant, Mahesasura, with his governor, Lembusura, who had the undying power. But once again the moral behind these stories is that the good will defeat evil.

3) The social educational values are apparent to those who are certainly aware of the idea of going up together with their friends and relatives to watch the artwork while sitting and behaving orderly and politely during the show. This will teach the importance of social life in the community to respect one another. In addition, the value of social education is from the Puppet Reog group whose dancers come from various different hamlets but they can still compactly perform the show.

4) Cultural educational values are also embedded in KSSS Puppet Reog shows as the public who watch this show can have a deeper sense of belonging to the local arts. Moreover, it can help preserve the art by taking care of Puppet Reog as a wealth of art from the local area. This can be clearly seen from the children who, after watching Puppet Reog, walked as if they were imitating the movements they had seen in the Puppet Reog show. If since childhood they grow their love for local art, the next generations will probably take care and support this Puppet Reog art better.

\section{Conclusions}

Based on the findings and discussion, this study formulates its conclusions by stating that the Puppet Reog presented by the Kanca Seni Sedulur Sinarawadhi is a form of Puppet Reog creative art which involves music and dance movements developed from classic Puppet Reog. The dance has been more dynamic as the accompaniment music can appropriately adjust to the motion of the figures, especially in the war segment. This dance focuses more on the war dance between the good line and the bad line where the good one contains Pandawa figures from the Mahabarata story and good figures from the Ramayana story such as monkey troops or rucah monkey, Subali, Sugriwa, and Hanoman or white apes who succeeds in defeating Dasamuka or Ravana. While the row that has evil characters are filled by Kurawa characters in the Baratayuda story and the giant forces, Mahesasura, Lembusura, and Rahwana from the Ramayana story.

The educational values contained in the Puppet Reog performance of the KSSS group include, first, the religious educational values that teach religious teachings. The second is moral education as displayed from this Puppet Reog story, in which evil will be inferior to goodness. Lastly, there exist 
social educational values that teach how to live in a society or to be mature individuals who live side by side with the community. Finally, it is a cultural value that teaches the public to love and support the local arts.

\section{REFERENCES}

[1] Thwaites, Tony, Lloyd Davis, and Warwick Mules. Tools for Cultural Studies: An Introduction, South Melbourne, Macmillan (1994).

[2] Ambroise, Yvon SJ [1987] makalah dalam Seminar Pendidikan non Formal, Bali., unpublished.

[3] Salahudin, Anas, and Irwanto Alkrienciehie. "Pendidikan Karakter: Pendidikan Berbasis Agama \&
Budaya Bangsa [Character Education: Education Based on Religion and Culture].” Pustaka Setia, 2013.

[4] Suhartono, Suparlan. "Wawasan Pendidikan : Sebuah pengantar Pendidikan [Educational Insights: an Introduction on Education]." Yogyakarta: ArRuzzmedia (2008).

[5] Spradley, James P. "Metode Etnografi [Ethnographic Mothods]." Yogyakarta: PT. Tiara Wacana 5 (1997).

[6] Creswell, John W. "Penelitian Kualitatif \& Desain Riset Memilih Diantara Lima Pendekatan [Qualitative Research \& Research Design on Choosing between Five Approaches]." Yogyakarta: Pustaka Pelajar (2015). 